\section{Effects of Mulch Type and Fertilizer Placement on Weed Growth and Soil pH and Nutrient Content}

\author{
Timothy K. Broschat
}

AdDITIONAL INDEX WORDS. cypress mulch, pine bark mulch, eucalyptus mulch, pine needle mulch, nitrogen, potassium, magnesium

SUMMARY. Four different organic mulches were applied to $1-\mathrm{m}^{2}$ plots of Margate fine sand soil that were irrigated three times per week. A $8 \mathrm{~N}-0.9 \mathrm{P}-10 \mathrm{~K}-4 \mathrm{Mg}$ controlled-release fertilizer was applied above or below these mulches to determine the effects of fertilizer placement on weed growth and soil $\mathrm{pH}$, nitrate-nitrogen, ammonium-nitrogen, potassium $(\mathrm{K})$, and magnesium $(\mathrm{Mg})$ concentrations. Unfertilized plots were used to determine mulch effects on soil $\mathrm{pH}$ and nutrient content. Fertilizer placement generally had no effect on any of these soil fertility parameters nor did it affect weed numbers. Cypress mulch increased soil $\mathrm{K}$ concentrations, and pine bark and eucalyptus mulch increased soil $\mathrm{Mg}$ over that of unmulched plots when no fertilizer was applied. The presence of any mulch type greatly reduced weed numbers over that of unmulched plots.

$\mathrm{T}$ The use of organic mulches around the bases of landscape plants has been widely advocated (Black and Ruppert, 1995; Thomas, 2002). Benefits of mulching include soil moisture retention (Ashworth and Harrison, 1983; Greenly and Rakow, 1995; Tukey and Schoff, 1963), reduction of soil temperatures (Ashworth and Harrison, 1983; Greenly and Rakow, 1995; Stinson et al., 1990), weed growth reduction (Ashworth and Harrison, 1983; Billeaud and Zajicek, 1989; Stinson et al., 1990), enhanced plant growth (Brown, 1996; Greenly and Rakow, 1995), improved penetration of irrigation or rainfall (Oliveira and Merwin, 2001), and enhanced nutrient availability (Tukey and Schoff, 1963). Potential problems associated with organic mulches are reduced nitrogen availability (Billeaud and Zajicek, 1989), water repellency (Gartner, 1978), and allelopathy (Duryea et al., 1999; Still et al., 1976).

One question that is often asked by landscapers is whether fertilizers should be applied above or below the mulch layer. Gilman et al. (1990)

Fort Lauderdale Research and Education Center, Environmental Horticulture Department, University of Florida, 3205 College Avenue, Fort Lauderdale, FL 33314

This research was supported by the Florida Agricultural Experiment Station.

I thank Susan Thor, Anita Durden, and William Latham for their assistance in this study. E-mail: tkbr@ufl.edu concluded from column leaching studies through cypress wood chips that $\mathrm{NH}_{4}-\mathrm{N}$ and $\mathrm{NO}_{3}-\mathrm{N}$ readily leached through this commonly used mulch material. However, as organic mulches decay, they may use $\mathrm{N}$ in the process (Ashworth and Harrison, 1983). Billeaud and Zajicek (1989) and Sonsteby et al. (2004) found that soil $\mathrm{N}$ in mulched plots was lower than in unmulched plots. Brown (1996), as well as Tukey and Schoff (1963), compared $\mathrm{pH}$ and soil phosphorus $(\mathrm{P})$, potassium $(\mathrm{K})$, and magnesium $(\mathrm{Mg})$ concentrations in plots mulched with organic mulches or none, but we are unaware of any studies documenting the effects of above versus below mulch applications of fertilizers on soil nutrient concentrations. The objectives of this study were to compare soil $\mathrm{pH}$ and nutrient contents as well as weed growth in plots mulched with four different organic mulches with fertilizer applied above or below the mulch.

\section{Materials and methods}

A $10 \times 10-\mathrm{m}$ area of land at the University of Florida's Fort Lauderdale Research and Education Center (lat. $26^{\circ} 5^{\prime} 5.6^{\prime \prime} \mathrm{N}$, long. $80^{\circ} 14^{\prime} 34.6^{\prime \prime} \mathrm{W}$ ) having a $0^{\circ}$ slope and a Margate fine sand soil was used for this study. This soil has a cation exchange capacity of $5.6 \mathrm{meq} \cdot 100 \mathrm{~g}$ (U.S. Dept. of Agriculture, 1984). Other chemical properties of the soil in these plots are presented in Table 1. The existing vegetation, consisting of a sparse cover of bahiagrass (Paspalum notatum) and various weed species, was sprayed with glyphosate l week before experiment initiation. A factorial experiment with five mulch treatments and three fertilizer treatments was set up using $1 \times 1-\mathrm{m}$ plots as the experimental units. There were six replications of each mulch-fertilizer combination arranged in a completely randomized design. Mulch treatments were: 1) no mulch, 2 ) coarse ( 2 to 4 inches long $\times 1$ to 2 inches wide $\times 1 / 4$ to $1 / 2$ inch thick) pine (Pinus elliottii) bark mulch ( $\mathrm{pH} 3.6), 3$ ) finely shredded eucalyptus (Eucalyptusspp.) wood mulch $(\mathrm{pH} 4.6), 4)$ finely shredded cypress (Taxodium distichum) wood chip mulch ( $\mathrm{pH} 4.8$ ), and 5) pine (Pinus elliottii) needle mulch $(\mathrm{pH}$ 4.4). Two cubic feet of each mulch was spread out uniformly on each plot resulting in an average depth of 2.2 inches. A $8 \mathrm{~N}-0.9 \mathrm{P}-10 \mathrm{~K}-4 \mathrm{Mg}$ landscape fertilizer with controlled-release nitrogen $(\mathrm{N}), \mathrm{K}$, and $\mathrm{Mg}$ (Nurserymen's Sure Gro Corp., Vero Beach, Fla.) was applied at a rate of $73 \mathrm{~g} \cdot \mathrm{m}^{-2}$ using a drop spreader (Lesco, Rocky River, Ohio) according to the following treatments: 1) fertilizer applied before mulching or 2 ) fertilizer applied after mulching. Six additional plots of each mulch treatment received no fertilizer to determine the effects of the mulches themselves on soil $\mathrm{pH}$ and nutrient contents. Irrigation from a

\begin{tabular}{llll}
\hline $\begin{array}{l}\text { Units } \\
\text { To convert U.S. to SI, } \\
\text { multiply by }\end{array}$ & U.S. unit & SI unit & $\begin{array}{l}\text { To convert SI to U.S., } \\
\text { multiply by }\end{array}$ \\
\hline 0.3048 & $\mathrm{ft}$ & $\mathrm{m}$ & 3.2808 \\
0.0929 & $\mathrm{ft}^{2}$ & $\mathrm{~m}^{2}$ & 10.7639 \\
0.0283 & $\mathrm{ft}^{3}$ & $\mathrm{~m}^{3}$ & 35.3147 \\
2.5400 & inch(es) & $\mathrm{cm}$ & 0.3937 \\
305.1517 & $\mathrm{oz} \cdot \mathrm{ft}^{2}$ & $\mathrm{~g} \cdot \mathrm{m}^{-2}$ & 0.0033 \\
1 & $\mathrm{ppm}$ & $\mu \mathrm{g} \cdot \mathrm{g}^{-1}$ & 1 \\
1 & $\mathrm{ppm}$ & $\mu \mathrm{g} \cdot \mathrm{cm}^{-3}$ & 1 \\
1 & $\mathrm{ppm}$ & $\mu \mathrm{g} \cdot \mathrm{mL}^{-1}$ & 1
\end{tabular}


Table 1. Effects of mulch type on unfertilized soil $\mathrm{pH}$ and extractable potassium $(\mathrm{K})$ and magnesium $(\mathrm{Mg})$ concentrations.

\begin{tabular}{|c|c|c|c|c|c|c|}
\hline \multirow[b]{2}{*}{ Mulch } & \multicolumn{3}{|c|}{ Expt. 1} & \multicolumn{3}{|c|}{ Expt. 2} \\
\hline & $\mathrm{pH}$ & $\begin{array}{c}\mathrm{K} \\
\left(\mu \mathrm{g} \cdot \mathrm{g}^{-1}\right)^{\mathrm{y}}\end{array}$ & $\begin{array}{c}\mathbf{M g} \\
\left(\mu \mathrm{g} \cdot \mathrm{g}^{-1}\right)\end{array}$ & $\mathrm{pH}$ & $\begin{array}{c}\mathrm{K} \\
\left(\mu \mathrm{g} \cdot \mathrm{g}^{-1}\right)\end{array}$ & $\begin{array}{c}\mathbf{M g} \\
\left(\mu \mathrm{g} \cdot \mathrm{g}^{-1}\right)\end{array}$ \\
\hline No mulch & 6.56 & 72.0 & 91.3 & 5.52 & $43.3 b^{z}$ & $62.8 \mathrm{~b}$ \\
\hline Pine bark & 6.67 & 81.0 & 93.0 & 5.65 & $61.0 \mathrm{ab}$ & $91.2 \mathrm{a}$ \\
\hline Eucalyptus & 6.46 & 69.3 & 97.7 & 5.15 & $62.8 \mathrm{ab}$ & $84.3 \mathrm{a}$ \\
\hline Cypress & 6.34 & 79.3 & 82.0 & 5.32 & 79.7 a & $76.8 \mathrm{ab}$ \\
\hline Pine needles & 6.18 & 57.5 & 71.8 & 5.22 & $51.7 \mathrm{~b}$ & $76.3 \mathrm{~b}$ \\
\hline
\end{tabular}

${ }^{2}$ Mean separation within columns by the Waller-Duncan k-ratio method $(P=0.05)$.

${ }^{y} 1 \mu \mathrm{g} \cdot \mathrm{g}^{-1}=1 \mathrm{ppm}$

single rotary head (Pro Plus model 11003; K-rain, West Palm Beach, Fla.) mounted on a centrally located 2 -fthigh riser provided $\approx 0.5$ inch of water every $3 \mathrm{~d}$. Irrigation water was drawn from a pond and had a $\mathrm{pH}$ of 7.2 during the first experiment (Expt. 1) and 6.8 during the second experiment (Expt. 2). This water contained 0.5 $\mu \mathrm{g} \cdot \mathrm{mL}^{-1}$ of $\mathrm{K}$ and $1.4 \mu \mathrm{g} \cdot \mathrm{mL}^{-1}$ of $\mathrm{Mg}$.

Expt. I was established on 14 Nov. 2003 and was ended 6 months later. The entire experiment was repeated on an adjacent block of land beginning on 25 June 2004 and ended 6 months later. Expt. 1 was conducted during the "dry season" (total rainfall $=12.8$ inches, rainfall during first 6 weeks $=1.1$ inches) in southern Florida, whereas the second was done during the "rainy season" (total rainfall $=33.4$ inches, rainfall during the first 6 weeks $=13.7$ inches). Rainfall data were obtained from the Florida Automated Weather Network [FAWN (Univ. of Florida, 2006)], which maintains a recording station $\approx 200 \mathrm{~m}$ from the research plots.

Six weeks after initiation of each experiment, soil core samples were taken from each plot for nutrient extractions. Sampling was done by scraping aside any mulch and taking a core of soil $2 \mathrm{~cm}$ in diameter $\times 10 \mathrm{~cm}$ deep. The top $2 \mathrm{~cm}$ of each core was discarded to prevent possible contamination by fertilizer prills and three cores per plot were pooled for analysis. Soil $\mathrm{pH}$ was determined from deionized water extractions, nitrate-nitrogen $\left(\mathrm{NO}_{3}-\mathrm{N}\right)$ and ammonium-nitrogen $\left(\mathrm{NH}_{4}-\mathrm{N}\right)$ were extracted with $2 \mathrm{M}$ potassium chloride (Mulvaney, 1996; Thomas, 1996), and soil $\mathrm{K}$ and $\mathrm{Mg}$ were extracted with $1 \mathrm{M}$ ammonium acetate (Helmke and Sparks, 1996; Suarez, 1996). $\mathrm{NO}_{3}-\mathrm{N}, \mathrm{NH}_{4}-\mathrm{N}$, and $\mathrm{pH}$ were determined by selective ion electrodes (Mulvaney, 1996; Thomas, 1996), whereas $\mathrm{K}$ and $\mathrm{Mg}$ concentrations were determined using atomic absorption spectroscopy (Helmke and Sparks, 1996; Suarez, 1996).

After 6 months, all weeds growing in each plot were counted and categorized as dicots [primarily large flower pusley (Richardia grandiflora)] or grasses [primarily torpedograss (Panicum repens) ]. All data were analyzed using analysis of variance with mean separations by the Waller-
Duncan k-ratio method (SAS Institute, Cary, N.C.).

\section{Results and discussion}

The numbers of dicot and total weeds per plot were significantly greater for unmulched plots than for plots mulched with any type of mulch in both experiments (Table 2). The number of grass weeds did not differ between mulched and unmulched plots because the predominant grass weed, torpedograss, spreads vegetatively through underground stolons as opposed to seedlings, which can be suppressed by mulches. In general, mulch type had no effect on the numbers of any type of weed. Likewise, fertilizer placement above or below the mulch layer had no effect on numbers of any type of weeds.

Soil $\mathrm{pH}$ was unaffected by mulch treatment or fertilizer (Table 3). Tukey and Schoff (1963) also found that mulching materials had no consistent effect on soil pH. However, other studies have shown that soil $\mathrm{pH}$ decreases when organic mulches are used and that this decrease is proportional to the depth of these mulches (Billeaud and Zajicek, 1989). Our soil samples were taken after 6 weeks, compared with 6 months for the latter study, and our shorter equilibration time may have influenced our results. Soil $\mathrm{pH}$ was consistently higher across all treatments in Expt. 1 than in Expt. 2. This may have been the result of the slightly higher $\mathrm{pH}$ of the irrigation water during Expt. 1 than during Expt. 2.

Nitrate- $\mathrm{N}$ in soil extracts was below $1 \mu \mathrm{g} \cdot \mathrm{g}^{-1}$ for all treatments (data not shown). Neither mulch presence or type nor fertilizer placement had any effect on soil $\mathrm{NH}_{4}-\mathrm{N}$

Table 2. Effects of mulch type and placement of an $8 \mathrm{~N}-0.9 \mathrm{P}-10 \mathrm{~K}-4 \mathrm{Mg}$ fertilizer above and below the mulch layer on numbers of dicot weeds, grass weeds, and total weeds per $1-\mathrm{m}^{2}\left(10.8-\mathrm{ft}^{2}\right)$ plot.

\begin{tabular}{|c|c|c|c|c|c|c|c|}
\hline \multirow[b]{2}{*}{ Mulch } & \multirow[b]{2}{*}{ Fertilizer placement } & \multicolumn{3}{|c|}{ Expt. 1} & \multicolumn{3}{|c|}{ Expt. 2} \\
\hline & & $\begin{array}{c}\text { Dicot weeds } \\
\left(\text { no. } / \mathrm{m}^{2}\right)\end{array}$ & $\begin{array}{c}\text { Grass weeds } \\
\left(\text { no. } / \mathrm{m}^{2}\right)\end{array}$ & $\begin{array}{c}\text { Total weeds } \\
\left(\text { no. } / \mathrm{m}^{2}\right)\end{array}$ & $\begin{array}{c}\text { Dicot weeds } \\
\left(\text { no. } / \mathrm{m}^{2}\right)\end{array}$ & $\begin{array}{c}\text { Grass weeds } \\
\left(\text { no. } / \mathrm{m}^{2}\right)\end{array}$ & $\begin{array}{c}\text { Total weeds } \\
\left(\text { no. } / \mathbf{m}^{2}\right)\end{array}$ \\
\hline Pine bark & & $5.2 \mathrm{~b}$ & 6.8 & $11.9 \mathrm{~b}$ & $114 \mathrm{~b}$ & 10.3 & $124 \mathrm{~b}$ \\
\hline Eucalyptus & & $4.3 \mathrm{~b}$ & 13.2 & $17.4 \mathrm{ab}$ & $147 \mathrm{~b}$ & 8.9 & $156 \mathrm{~b}$ \\
\hline Cypress & & $3.2 \mathrm{~b}$ & 9.6 & $12.8 \mathrm{ab}$ & $149 \mathrm{~b}$ & 21.0 & $170 \mathrm{~b}$ \\
\hline & Above mulch & $5.2 \mathrm{~b}$ & 9.1 & $14.3 \mathrm{ab}$ & $138 \mathrm{~b}$ & 13.8 & $152 \mathrm{~b}$ \\
\hline & Below mulch & $4.3 \mathrm{~b}$ & 8.9 & $13.3 \mathrm{~b}$ & $103 \mathrm{~b}$ & 13.4 & $116 \mathrm{~b}$ \\
\hline
\end{tabular}

${ }^{\mathrm{z}}$ Mean separation within columns and subsections by the Waller-Duncan k-ratio method $(P=0.05)$.

${ }^{\mathrm{y}} 1$ weed $\cdot \mathrm{m}^{2}=0.0929$ weed $\cdot \mathrm{ft}^{2}$. 
Table 3. Effects of mulch type and placement of an $8 \mathrm{~N}-0.9 \mathrm{P}-10 \mathrm{~K}-4 \mathrm{Mg}$ fertilizer above and below the mulch layer on soil $\mathrm{pH}$ and extractable potassium $(\mathrm{K})$ and magnesium $(\mathrm{Mg})$ concentrations.

\begin{tabular}{|c|c|c|c|c|c|c|c|}
\hline \multirow[b]{2}{*}{ Mulch } & \multirow[b]{2}{*}{$\begin{array}{c}\text { Fertilizer } \\
\text { placement }\end{array}$} & \multicolumn{3}{|c|}{ Expt. 1} & \multicolumn{3}{|c|}{ Expt. 2} \\
\hline & & $\mathrm{pH}$ & $\begin{array}{c}\mathrm{K} \\
\left(\mu \mathrm{g} \cdot \mathrm{g}^{-1}\right)^{\mathrm{y}}\end{array}$ & $\begin{array}{c}\mathbf{M g} \\
\left(\mu \mathrm{g} \cdot \mathrm{g}^{-1}\right)\end{array}$ & $\mathrm{pH}$ & $\begin{array}{c}\mathrm{K} \\
\left(\mu \mathrm{g} \cdot \mathrm{g}^{-1}\right)\end{array}$ & $\begin{array}{c}\mathrm{Mg} \\
\left(\mu \mathrm{g} \cdot \mathrm{g}^{-1}\right)\end{array}$ \\
\hline No mulch & & 6.54 & 178 & 112 & 5.44 & $66 c^{z}$ & 81 \\
\hline Pine bark & & 6.65 & 137 & 92 & 4.81 & $116 \mathrm{ab}$ & 87 \\
\hline Eucalyptus & & 6.39 & 159 & 91 & 5.23 & $115 \mathrm{ab}$ & 82 \\
\hline Cypress & & 6.44 & 160 & 110 & 5.32 & $142 \mathrm{a}$ & 88 \\
\hline Pine needles & & 6.59 & 147 & 102 & 5.55 & $108 \mathrm{~b}$ & 93 \\
\hline & No mulch & 6.51 & $178 \mathrm{a}$ & 112 & 5.45 & $66 \mathrm{~b}$ & 81 \\
\hline & Above mulch & 6.37 & $134 \mathrm{~b}$ & 96 & 5.23 & $112 \mathrm{a}$ & 89 \\
\hline & Below mulch & 6.62 & $169 \mathrm{a}$ & 102 & 5.22 & $127 \mathrm{a}$ & 85 \\
\hline
\end{tabular}

${ }^{\mathrm{z}}$ Mean separation within columns and subsections by the Waller-Duncan k-ratio method $(P=0.05)$.

${ }^{\mathrm{y}} 1 \mu \mathrm{g} \cdot \mathrm{g}^{-1}=1 \mathrm{ppm}$

concentrations in either experiment with values ranging from 7 to 10 $\mu \mathrm{g} \cdot \mathrm{g}^{-1}$ for all treatments (data not shown). Likewise, neither mulch presence nor type affected soil $\mathrm{NH}_{4}-$ $\mathrm{N}$ concentrations in unfertilized plots, which were similar to those of the fertilized plots (data not shown). On the other hand, Sonsteby et al. (2004) found that soil $\mathrm{NO}_{3}-\mathrm{N}$ and $\mathrm{NH}_{4}-\mathrm{N}$ were significantly decreased when spruce (Picea spp.) bark was applied to an unfertilized morainic loam soil. Their different response may have been the result of a much longer time that the soil was exposed to mulch before sampling ( 3 years vs. 6 weeks).

Mulch type generally had no effect on soil $\mathrm{K}$ and $\mathrm{Mg}$ concentrations, but in Expt. 2, soil $\mathrm{K}$ concentrations in plots with no mulch were lower than any mulched plots (Table 3). Tukey and Schoff (1963) found that plots mulched with organic materials had significantly higher soil $\mathrm{K}$, but not $\mathrm{Mg}$, concentrations than unmulched plots. They attributed this to $\mathrm{K}$ release during the decomposition of the mulch materials. When we compared soil $\mathrm{K}$ and $\mathrm{Mg}$ concentrations in unfertilized plots, we found that the presence of cypress mulch significantly increased soil $\mathrm{K}$ concentrations above that of unmulched plots in Expt. 2 (Table 1). Water-extractable $\mathrm{K}$ concentrations in cypress, melaleuca, pine bark, and pine needle mulches of $\approx 60,69,78$, and 41 $\mu \mathrm{g} \cdot \mathrm{cm}^{-3}$, respectively, represent significant contributions of this element to soil fertility.

Both pine bark and eucalyptus mulch increased soil $\mathrm{Mg}$ concentrations above that of unmulched control plots in Expt. 2 (Table 1). Water-extractable Mg concentrations in cypress, melaleuca, pine bark, and pine needle mulches were $\approx 3,7,10$, and $9 \mu \mathrm{g} \cdot \mathrm{cm}^{-3}$, respectively. These concentrations of $\mathrm{Mg}$ are considerably lower than those for $\mathrm{K}$ but could still potentially influence soil $\mathrm{Mg}$ concentrations. Interactive effects of mulch type and fertilizer placement on soil $\mathrm{K}$ and $\mathrm{Mg}$ concentrations were not significant in either experiment.

Although fertilizer placed below mulch resulted in higher soil $\mathrm{K}$ concentrations than fertilizer placed above mulch in Expt. 1 plots, that trend was not statistically significant in Expt. 2 plots (Table 3). This suggests that some $\mathrm{K}$ may have been adsorbed to mulch particles, which retarded the leaching of this element into the soil. Similar effects might also have been expected for $\mathrm{Mg}$, although fertilizer placement had no consistent effects on soil $\mathrm{Mg}$ concentrations.

In summary, organic mulch of any type greatly reduced dicot weed numbers with no one type superior to any other. Certain types of mulches such as cypress, pine bark, or eucalyptus mulch by themselves increased soil $\mathrm{K}$ or $\mathrm{Mg}$ concentrations, but none affected soil $\mathrm{N}$ concentrations. Fertilizer placement above or below mulch had little or no effect on soil nutrient concentrations and thus there appears to be no advantage to applying fertilizers under mulches. These conclusions are based on soil sampling 6 weeks after mulching and fertilization and results may differ if sampling is done after longer time intervals after mulch and fertilizer application or under different environmental conditions.

\section{Literature cited}

Ashworth, S. and H. Harrison. 1983. Evaluation of mulches for use in the home garden. HortScience 18:180-182.

Billeaud, L.A. and J.M. Zajicek. 1989. Influence of mulches on weed control, soil $\mathrm{pH}$, soil nitrogen content, and growth of Ligustrum japonicum. J. Environ. Hort. 7:155-157.

Black, R.J. and K.C. Ruppert. 1995. Your Florida landscape: A complete guide to planting and maintenance. Univ. Fla. Coop. Ext. Serv. Publ. SP135.

Brown, S.H. 1996. Response of hibiscus to organic mulches. Proc. Florida State Hort. Soc. 109:30-33

Duryea, M.L., R.J. English, and L.A. Hermansen. 1999. A comparison of landscape mulches: Chemical, allelopathic, and decomposition properties. J. Arboriculture 25:88-96.

Gartner, J.B. 1978. Using bark and wood chips as a mulch for shrubs and evergreens. Amer. Nurseryman 147:9, 53-55.

Gilman, E.F., T.H. Yeager, and D. Weigle. 1990. Nitrogen leaching from cypress wood chips. HortScience 25:1388-1390.

Greenly, K.M. and D.A. Rakow. 1995. The effect of wood mulch type and depth on weed and tree growth and certain soil parameters. J. Arboriculture 21:225-232.

Helmke, P.A. and D.L. Sparks. 1996. Lithium, sodium, potassium, rubidium, and cesium, p. 551-574. In: D.L. Sparks (ed.). Methods of soil analysis. Part 3. Chemical methods. Soil Sci. Soc. Amer, Madison, Wis.

Mulvaney, R.L. 1996. Nitrogen-inorganic forms, p. 1123-1184. In: D.L. Sparks (ed.). Methods of soil analysis. Part 3. Chemical methods. Soil Sci. Soc. Amer., Madison, Wis.

Oliveira, M.T. and I.A. Merwin. 2001. Soil physical conditions in a New York orchard after eight years under different groundcover management systems. Plant Soil 234:233-237.

Sonsteby, A., A. Nes, and F. Mage. 2004. Effects of bark mulch and $\mathrm{N}-\mathrm{P}-\mathrm{K}$ fertilizer on yield, leaf nutrient status, and soil mineral nitrogen during three years of production. Acta Agriculturae Scandinavica. Section B (Soil and Plant Science) 54:128-134.

Still, S.T., M.A. Dirr, and J.B. Gartner. 1976. Phytotoxic effects of several bark extracts on mung bean and cucumber growth. J. Amer. Soc. Hort. Sci. 101:34-37.

Stinson, J.M., G.H. Brinen, D.B. McConnell, and R.J. Black. 1990. Evaluation of landscape mulches. Proc. Florida State Hort. Soc. 103:372-377. 
Suarez, D.L. 1996. Beryllium, magnesium, calcium, strontium, and barium, p. 575-602. In: D.L. Sparks (ed.). Methods of soil analysis. Part 3. Chemical methods. Soil Sci. Soc. Amer., Madison, Wis.

Thomas, G.W. 1996. Soil pH and soil acidity, p. 475-490. In: D.L. Sparks (ed.). Methods of soil analysis. Part 3. Chemical methods. Soil Sci. Soc. Amer., Madison, Wis.
Thomas M. (ed.). 2002. Best management practices for protection of water resources in Florida. Florida Dept. Environ. Protection, Tallahassee.

Tukey, R.B. and E.L. Schoff. 1963. Influence of different mulching materials upon the soil environment. Proc. Amer. Soc. Hort. Sci. 82:69-76.
Univ. of Florida. 2006. Florida automated weather network. 6 Nov. 2006. <http://fawn.ifas.ufl.edu/scripts/ reportrequest.asp $>$.

U.S. Dept. of Agriculture. 1984. Soil survey of Broward County, Florida, Eastern part. Soil Conserv. Serv., U.S. States Dept. Agr., Washington, D.C. 